\title{
LIGHTNESS FACTORS AND EXERTION FACTORS RELATED TO ITS OWN MASS OF FIBER REINFORCED PLASTICS (FRP) APPLIED IN COMPOSITE AERONAUTICAL STRUCTURES (Part 1) \\ WSKAŹNIKI LEKKOŚCI ORAZ WSKAŹNIKI WYSIEKU STRUKTURY W ODNIESIENIU DO WLASNEJ MASY WLÓKNISTYCH KOMPOZYTÓW POLIMEROWYCH STOSOWANYCH W STRUKTURACH LOTNICZYCH (Część 1)
}

\author{
Mirosław Rodzewicz ${ }^{1}$, Jerzy Lewitowicz ${ }^{2}$ \\ ${ }^{1}$ Warsaw University of Technology. Politechnika Warszawska \\ ${ }^{2}$ Air Force Institute of Technology. Instytut Techniczny Wojsk Lotniczych
}

\begin{abstract}
The paper concerns an application of lightness factors in comparative analysis of strength properties of basic materials being applied in aeronautical structures - in a historical perspective. The use of lightness factors enables effective estimation how lighter will be the structural elements (of the same strength or stiffness ) made from different kind of materials : traditional as well as advanced composites. It is quite easy to find the solution to the inverse problem, i.e. to estimate how differ will be stiffness or strength for the same mass of the structural elements. Very particular application of the lightness factors are noted in engineers calculations of composite gliders wing spars, where they appears as the materials constants and as structure loading factors as well. The paper presents some examples of application of the lightness factors in strength analysis of the composite shells applied in the shear webs of the wing spars, and refers to the design recommendations issued by German aviation authority $(L B A)$.
\end{abstract}

Keywords: aircraft, composites

Streszczenie: $W$ pracy opisano wykorzystanie wskaźników lekkości $w$ analizie porównawczej właściwości wytrzymatościowych podstawowych materiatów konstrukcyjnych stosowanych $w$ budowie płatowców $w$ ujęciu historycznym. Zastosowanie wskaźników lekkości umożliwia szybkie oszacowanie o ile lżejsze będa przy tej samej wytrzymatości lub sztywności elementy strukturalne wykonane z różnego rodzaju materiałów - zarówno tradycyjnych, jak też różnych kompozytów polimerowych. Latwo jest również znaleźć rozwiazanie dla zagadnienia odwrotnego, tzn. oszacować ile będa różnić się sztywności lub wytrzymałości przy tej samej masie elementów strukturalnych. Wskaźniki lekkości znalazły szczególne zastosowanie $w$ inżynierskich obliczeniach kompozytowych dźwigarów skrzydel szybowców, występujac $w$ nich zarówno jako stałe materiałowe, oraz jako wskaźniki wytężenia struktury. W pracy podano przykłady zastosowania tych wskaźników do analizy powtok kompozytowych stosowanych w ściankach dźwigarów skrzydet oraz odniesiono się do zaleceń projektowych stosowanych przez niemiecki nadzór lotniczy (LBA).

Stowa kluczowe: statki powietrzne, kompozyty 
Lightness factors and exertion factors related to its own mass of fiber... (Part I) Wskaźniki lekkości oraz wskaźniki wysiłku struktury w odniesieniu do...(Część I)

\section{LIGHTNESS FACTORS AND EXERTION FACTORS RELATED TO ITS OWN MASS OF FIBER REINFORCED PLASTICS (FRP) APPLIED IN COMPOSITE AERONAUTICAL STRUCTURES (Part 1)}

\section{Introduction}

New materials have significant influence on technological development especially in aeronautics. As an example there is shown the graph concerning the performance of the gliders (Fig. 1) [1,3].

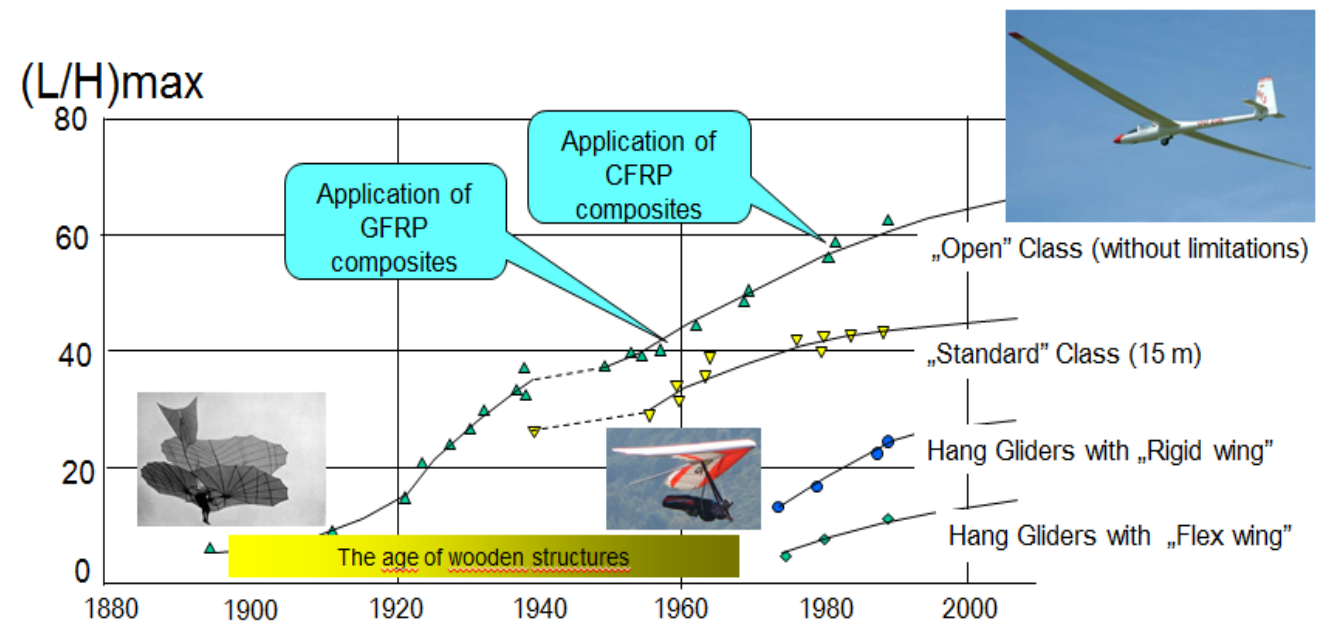

Fig. 1 Influence of new materials application on the gliders performance [2]

Aerodynamic performance is given by the ratio $c_{L}$ over $c_{D}$, where $c_{L}$ is a lift force coefficient, and $\mathrm{c}_{\mathrm{D}}$ is a drag force coefficient.

$$
\frac{L}{D}=\frac{c_{L}}{c_{D}}
$$

The formula for the drag force coefficient of the wing can be expressed as a sum of the following components, which refer to the drug produced by pure airfoil, induced drag generated by 3D flow around the wing, and the drug involved by the roughness of the wing surface:

$$
c_{D^{\prime}}=c_{D_{-} \text {airfoil }}+c_{D_{-} \text {induced }}+c_{D_{-} \text {rough }}
$$

The main component in this formula having the biggest significance is an induced drag coefficient. 
As one can see the induced drag is inverse proportional to the wing aspect ratio $\lambda$. So only in the case when the wing has a big span $b$ in comparison with the chord the induced drag is low.

$$
c_{D_{-} \text {induced }}=\frac{c_{L}^{2}}{\pi \cdot \lambda}=\frac{c_{L}^{2} \cdot S}{\pi \cdot b^{2}}
$$

Requirement of high aspect ratio creates several problems regarding materials and strength, since the wing of high performance glider works as a thin and slim beam. Therefore it must be designed with a proper safety margin, and own mass as small as possible. So the material properties have here crucial importance. Taking as an example the curve for the Open Class of (i.e. competition class of the glider without any design limitation) - one can see that the Fiber Reinforced composites enables to achieve much bigger glider performance than in case of other material. On the graph are presented in a schematic way the curves representing tensile strength properties of different materials used for airframe design nowadays and in the past. There are marked the ranges of a linear behavior (I mean operational range), and the values of elongation in the moment of the fracture.

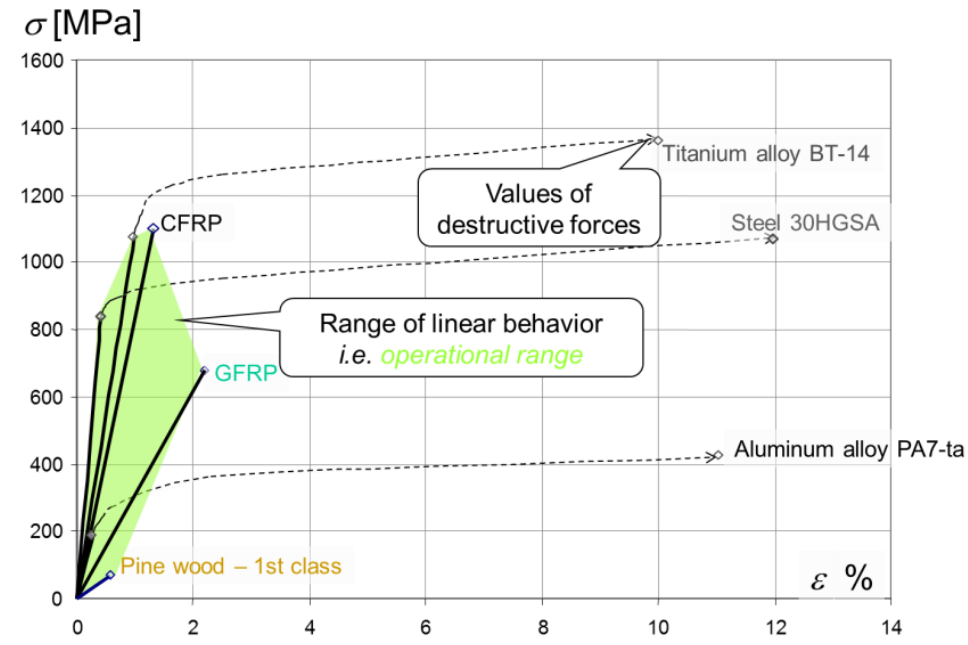

Fig. 2 Elastic and strength properties of some common materials used in aircraft structures

This is visible that the highest strength have the titanium alloy and the composite reinforced by carbon fibers. The steel has the biggest Young modulus, and the properties of the pine-wood look on this pattern very modest. But I it is necessary to point out, that in this analysis are taken into account only values of the strength in $\mathrm{MPa}$, while mass of the structure is neglected.

On the left side of Table 1 are grouped the numerical values of basic strength properties. 
Lightness factors and exertion factors related to its own mass of fiber... (Part I) Wskaźniki lekkości oraz wskaźniki wysitku struktury w odniesieniu do...(Część I)

Tab. 1 Absolute and specific values of strength properties of some common materials used in aircraft structures

\begin{tabular}{|l|c|c|c|c|c|c|c|c|}
\hline & $\begin{array}{l}\text { Tensile } \\
\text { strength }\end{array}$ & $\begin{array}{c}\text { Compression } \\
\text { strength }\end{array}$ & E-modulus & $\begin{array}{c}\text { Density } \\
\text { of } \\
\text { fibers }\end{array}$ & $\begin{array}{c}\text { Density } \\
\text { of } \\
\text { composite }\end{array}$ & $\begin{array}{c}\text { Specific } \\
\text { Tensile } \\
\text { strength }\end{array}$ & $\begin{array}{c}\text { Specific } \\
\text { Compression } \\
\text { strength }\end{array}$ & $\begin{array}{c}\text { Specific } \\
\text { stiffness }\end{array}$ \\
\hline & $R_{m}$ & $R_{c}$ & $E$ & $\rho$ & $\rho$ & $R_{m} /(\rho g)$ & $R_{c} /(\rho g)$ & $E /(\rho g)$ \\
\cline { 2 - 9 } & $\mathrm{MPa}$ & $\mathrm{MPa}$ & $\mathrm{GPa}$ & $\mathrm{g} / \mathrm{cm}^{3}$ & $\mathrm{~g} / \mathrm{cm}^{3}$ & $\mathrm{~km}$ & $\mathrm{~km}$ & $\mathrm{~km}$ \\
\hline GFRP & 680 & 600 & 35 & 2.55 & 1.875 & 37 & 33 & 1903 \\
\hline HT-CFRP & 1100 & 800 & 100 & 1.76 & 1.48 & 76 & 55 & 6888 \\
\hline HM-CFRP & 830 & 700 & 123 & 1.9 & 1.55 & 55 & 46 & 8089 \\
\hline AFRP & 790 & 180 & 44 & 1.45 & 1.325 & 61 & 14 & 3385 \\
\hline Titanium all. & 1400 & 1400 & 110 & - & 4.45 & 32 & 32 & 2520 \\
\hline Steel & 1100 & 1100 & 210 & - & 7.86 & 14 & 14 & 2724 \\
\hline Alum. all. & 420 & 420 & 72 & - & 2.8 & 15 & 15 & 2621 \\
\hline Pine wood & 69 & 39 & 12 & - & 0.46 & 15 & 9 & 2659 \\
\hline
\end{tabular}

If the only design criteria for stretched rods is the smallest cross-section, and the mass is not important - then without any doubts, the steel, titanium alloy or CFRP composite would be equivalent materials.

But in aeronautics we usually need the biggest strength or biggest stiffness from the mass unit of the structure. In this case the parameter more appropriate for comparison would be specific strength and specific stiffness. If one define them like in formulas existing in Table 1 , then the dimension of specific strength is meter or kilometer, and the numbers in the column means the length of the rod which will be broken by its own weight. If we compare those parameters - we may discover the supremacy of all kind of composites over metals.

And what is interesting: the steel, aluminum alloy and pine wood have almost similar values of specific strength and specific stiffness.

On the graph shown in Fig. 3 are grouped the tension or compression specific strength values vs specific stiffness.

The ratio of distance from the zero-zero coordinates of the points representing particular materials inform us how many times bigger strength or stiffness would have the rods of the same weight made from different materials, or how many times the particular rod would be lighter or heavier, when the strength or stiffness are the same. This graph reveals how big supremacy have the composites reinforced by carbon fibers. It is visible also, that the masses of structures made from traditional materials of the same strength or stiffness would be very similar, regardless they are made from wood, aluminum alloy or the steel. 


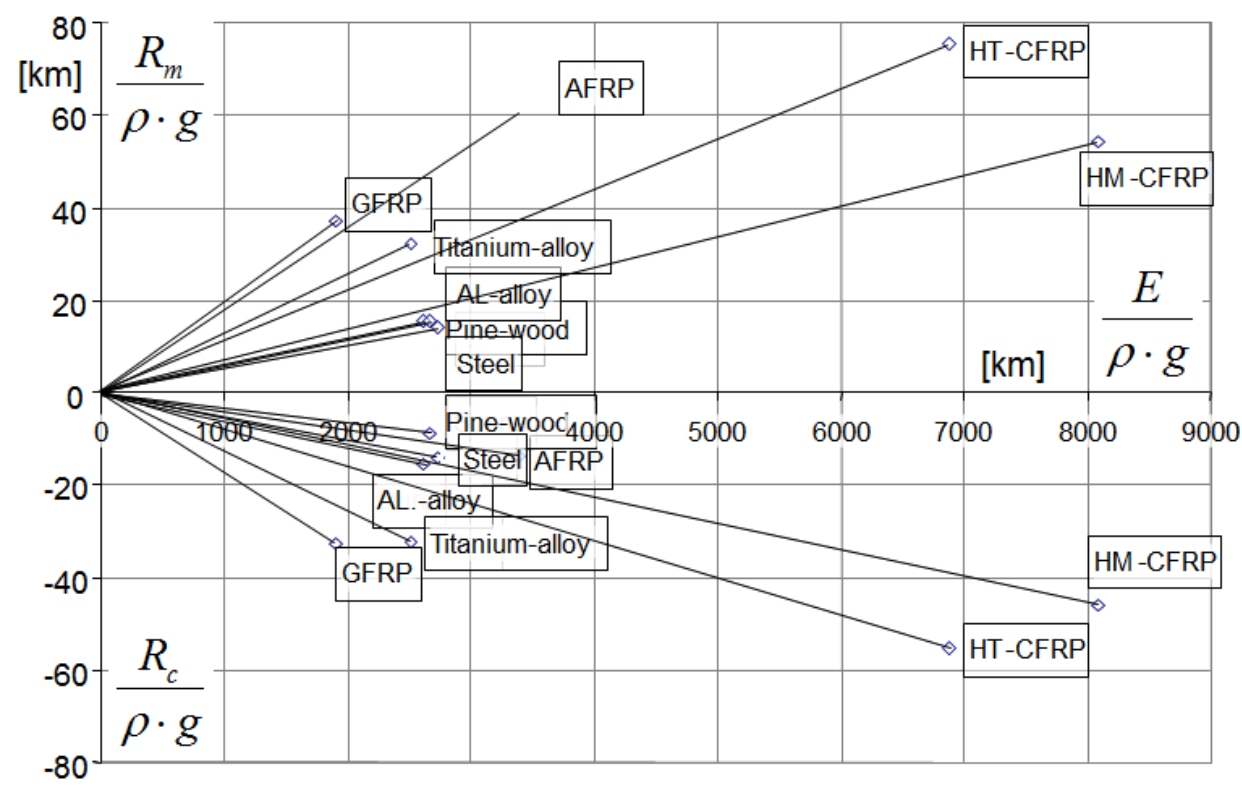

Fig. 3 Specific strength versus specific stiffness

\section{Lightness factors}

The specific stiffness or specific belong to numerous set of, so called, lightness factors. There are some more representatives of lightness factors. They are grouped in the table below:

Tab. 2 Lightness factors for different kinds of [1]

\begin{tabular}{|c|c|c|c|c|c|}
\hline $\begin{array}{c}\text { Structural } \\
\text { ellement }\end{array}$ & \multicolumn{2}{|c|}{ Rod } & $\begin{array}{c}\text { Thin-wall } \\
\text { shell }\end{array}$ & $\begin{array}{c}\text { Thin-wall } \\
\text { tube }\end{array}$ \\
\hline LOAD & Tension & \multicolumn{2}{|c|}{ Compression } & $\begin{array}{c}\text { Compression } \\
\text { buckling }\end{array}$ & $\begin{array}{c}\text { Torsional } \\
\text { buckling }\end{array}$ \\
\cline { 2 - 6 } & $\begin{array}{c}\text { Compression } \\
\text { case of } \\
\text { thickset rod }\end{array}$ & $\begin{array}{c}\text { Euler's buckling } \\
\text { (if value of rod-slenderness } \\
\text { is constant) }\end{array}$ & \multirow{2}{*}{$E^{1 / 3} / \rho$} & $E^{1 / 2} / \rho$ \\
\hline Lightness & $R_{m} / \rho$ & $R_{d} / \rho$ & $E / \rho$ & \\
\hline
\end{tabular}

In order to explain the genesis of those factors, the best way is to analyze the ratio of the masses of two structures, which are loaded in the same way up to ultimate values. 
Lightness factors and exertion factors related to its own mass of fiber... (Part I) Wskaźniki lekkości oraz wskaźniki wysiłku struktury w odniesieniu do...(Część I)

$$
\frac{m_{1}}{m_{2}}=? \quad \begin{aligned}
& \text { Comparison of structure masses which } \\
& \text { are able to sustain particular type of loading }
\end{aligned}
$$

For simplification it was assumed that the materials are quasi-isotropic and they elastic properties may be represented by single value of Young modulus $E$, which is relevant to the direction of load.

For example for the stretched rods this ratio can be expressed by this equation, and there are existing $R_{m}$ (tensile strength) and $p$ (density).

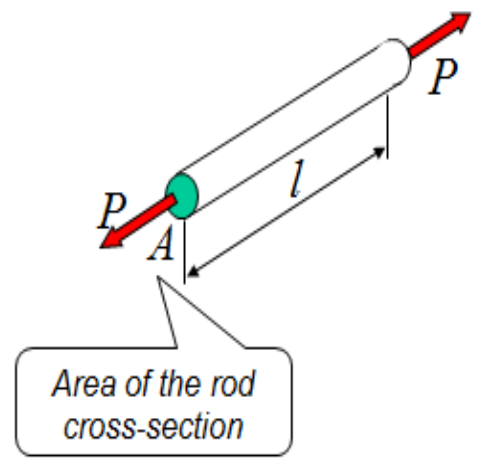

$$
\begin{aligned}
& P \rightarrow P_{\max } \\
& P_{\text {max }}=R_{m} A \quad m=A l \rho=\frac{P_{\max } l \rho}{R_{m}} \\
& \frac{m_{1}}{m_{2}}=\frac{P_{\max } l \rho_{1} R_{m 2}}{P_{\max } l \rho_{2} R_{m 1}}=\frac{R_{m 2} / \rho_{2}}{R_{m 1} / \rho_{1}}
\end{aligned}
$$

Fig. 4 Genesis of lightness factor for the rods subjected to tension load

For compressed rods, where Euler buckling model is applicable - this ratio is expressed by the following equation, and we have here $E$-modulus over density.

$$
\begin{gathered}
P \rightarrow P_{k r} \quad P \quad P_{k r}=\frac{c \cdot \Pi^{2} \cdot E \cdot J}{l^{2}}=\frac{c \cdot \Pi^{2} \cdot E \cdot A \cdot i^{2}}{l^{2}} \\
m=A l \rho=\frac{P_{k r} l^{2}}{c \Pi^{2} E i^{2}} l \rho=\frac{P_{k r} s^{2}}{c \Pi^{2} E} l \rho \\
\frac{m_{1}}{m_{2}}=\frac{E_{2} / \rho_{2}}{E_{1} / \rho_{1}} \quad \begin{array}{l}
\text { if slenderness ratio } \\
s=\frac{l}{i}=\text { const }
\end{array}
\end{gathered}
$$

Fig. 5 Genesis of lightness factor for the rods subjected to compression load 
In case of compressed shells the formula for lightness factor is given here:

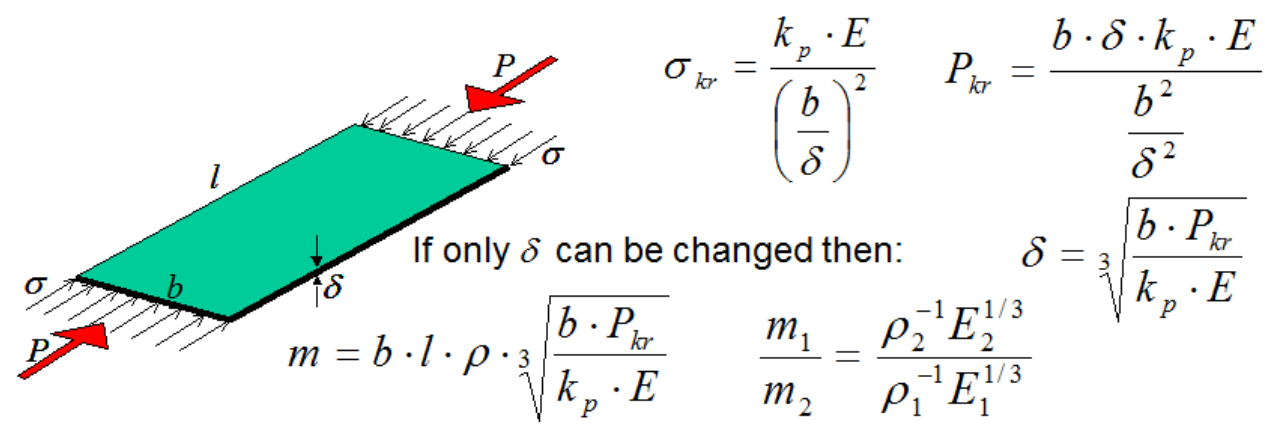

Fig. 6 Genesis of lightness factor for the shells subjected to compression load

Finally in case of twisted thin-wall tubes - the lightness factors is given by this equation.

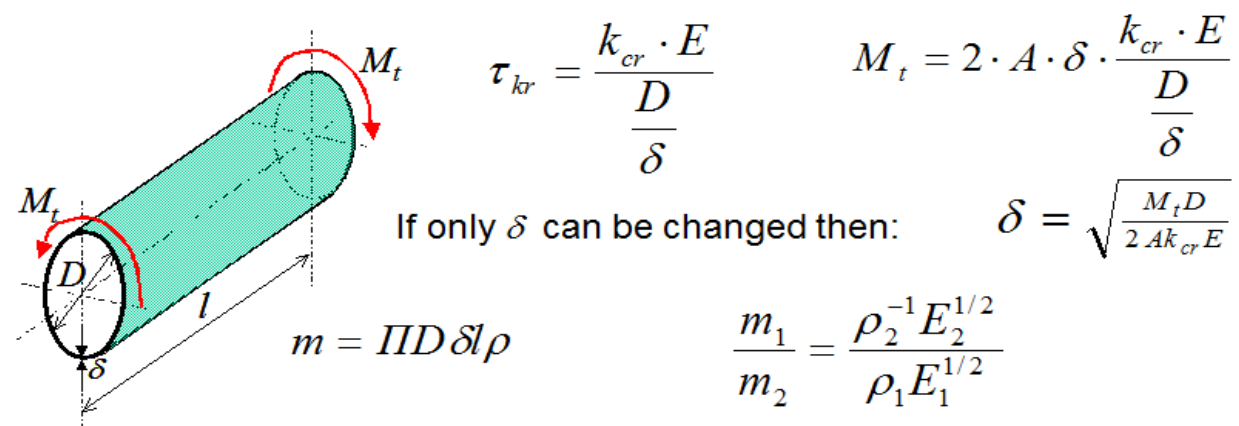

Fig. 7 Genesis of lightness factor for the thin-walled tubes subjected to torsion load

\section{Lightness factors \& Exertion factors of the FRP-structure -}

Calculation of exertion of a composite shell in respect to mass of fabric, which are used for reinforcement. Analogously like the lightness factors, in the 70s of the last century there were introduced into strength calculations of composite structures, so called, the exertion factors of the FRP-structure, (or in other words: the Structure Stress Rates - SSR). The exertion factor sometimes appears also in a present-day literature concerning composite gliders design. According the document issued by German Engineers Association VDI the exertion factor is defined by the following formula.

The definition of the SSR i.e. $\mathrm{K}_{\sigma}$ is done by the following expression: Where product $\sigma \cdot \delta$ means the compression or tensile force distribution along chosen direction of the fiber lay-out. 


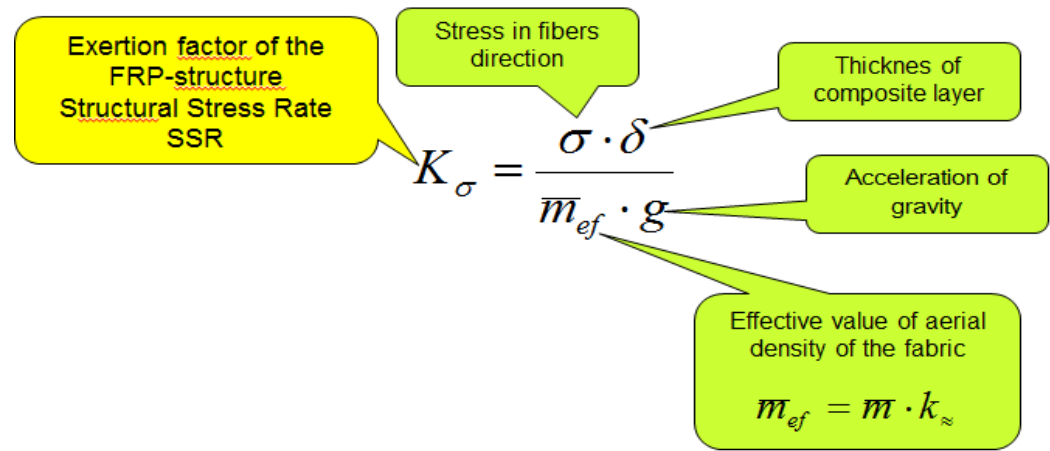

Fig. 8 Symbol $\bar{m}_{\text {ef }}$ means "effective areal density" and is defined by following formula

Where $\bar{m}$ is the catalogue value of an areal density of all fabrics in the laminate, and $k_{\approx}$ is a mass ratio of fibers which are employed to carry the load. For common fabrics with the same quantity of warp and weft fibers the $k_{\approx}=0.5$ when are subjected to tension (or to compression) along only one (i.e.: warp or weft) direction. Coefficient $g$ means gravity acceleration. The unit of $K_{\sigma}$ is [m].

In German literature one can find $K_{\sigma}$ associated by additional index $D$ or $Z$ ( which comes from German word "Drück" and "Zuck" i.e. "compression" and "tension"). It is worth to emphasis, that the biggest value of $\sigma$ can be tension or compression strength $R_{m}$ or $R_{c}$. The exertion factor for these values is named $K_{R m}$ or $K_{R c}$ and represents peculiar material constant. The value of $K_{R m}$ represents the maximum length of fabric consisting only from wrap or weft fibers (depending on the orientation of the fibers toward the tension load) which may endure the load produced by own weight. If one compare the value of $K_{\sigma}$ with the value of $K_{R m}$ or $K_{R c}$, then he may estimate the rate of usage of the loading ability of fabric used as the reinforcement of composite shell.

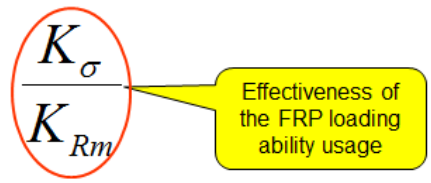

\section{Exertion factors of the FRP-structure and the method of laminate strength calculation}

Currently it is a common standard that for laminate strength calculations there are used stresses and strength constants expressed in MPa (taking into account the loads and cross-section areas of the laminate). Unfortunately the accuracy of stress or strength calculations depends on the accuracy of the thickness estimation of the laminate layer. The thickness of laminate layer depends on the volume of resin used for impregnation and on the method of manufacturing (i.e.: with the vacuumpressure or free forming). 
For example if someone uses twice more resin for single laminate layer impregnation - the thickness of the layer will increase, but the real strength will be still almost the same. So, if for strength calculation he takes catalog value of $R_{m}$ and thickness of such over-impregnated laminate - then he makes significant mistake. Therefore in the past there were applied the method of elimination the thickness layer from calculation formulas.

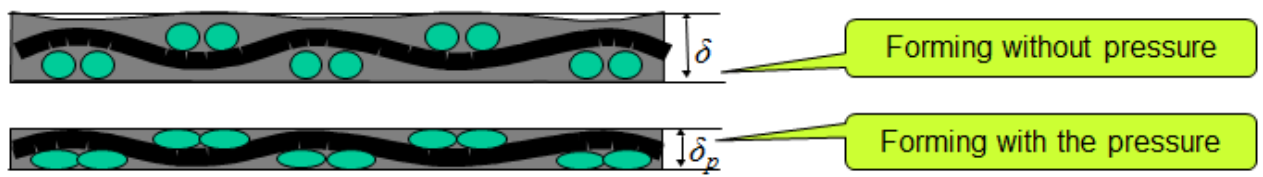

Fig. 9 Influence of manufacturing method on the laminate layer thickness, which generates the problem what thickness value should be taken for strength calculation

The idea of this method is presented in the Fig. 10. Instead stresses $\sigma$ or $\tau$ there is used load distribution $q_{\sigma}$ and $q_{\tau}$.

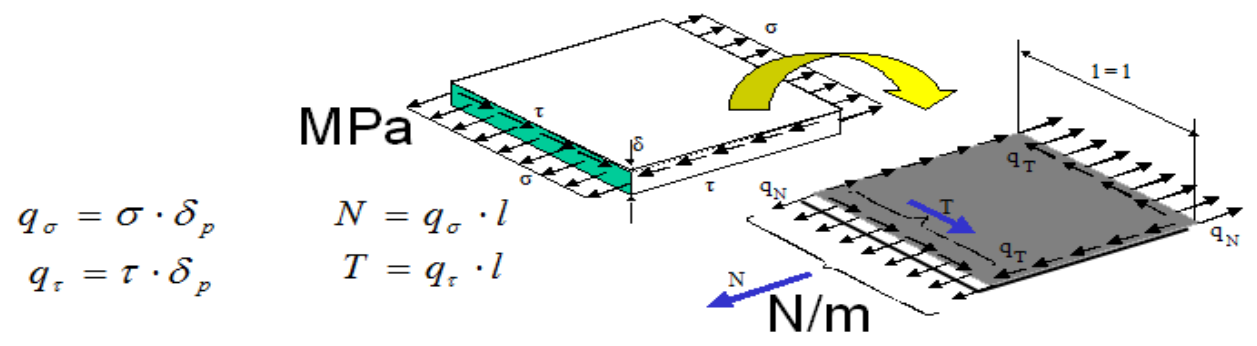

Fig. 10 Transition from systems "Force \& cross-section area" to "Load distribution along the edge \& edge length"

Consistently instead material constants $R_{m}, R_{c}, E, G$ (i.e. tensile strength, compression strength, $E$-modulus, $G$-modulus) are used $\bar{R}_{m}, \bar{R}_{c}, \bar{E}, \bar{G}$ where $R_{m}=R_{m} \cdot \delta$, etc. The unit of such a constant is $[\mathrm{N} / \mathrm{m}]$.

\section{Biblography}

[1] JBaker A. A.: Composite Materials for Aircraft Structures, Second Edition (AIAA Education Series), 2004.

[2] Kustron K.: The design technology development of prospective airframe in view of the operation\&maintenance experience and technology development, Journal of KONBiN 2 (22) 2012.

[3] Kensche Ch. W.: The influence of materials on the development of sailplane design, Technical Soaring, Volume XXVTT - July 2003

[4] Jancelewicz B.: Podstawy konstrukcji lotniczych z kompozytów polimerowych, Wyd. ITWL Warszawa 2000.

[5] Verein Deutscher Ingenieure: „Dimensionieren von Bauteilen as GFK” (Glasfaserstärkte Kunststoffe) - VDI 2013 Blatt 1, Düsseldorf 1973. 
Lightness factors and exertion factors related to its own mass of fiber... (Part I) Wskaźniki lekkości oraz wskaźniki wysiłku struktury w odniesieniu do...(Część I)

\section{WSKAŹNIKI LEKKOŚCI ORAZ WSKAŹNIKI WYSILKU STRUKTURY W ODNIESIENIU DO WLASNEJ MASY WLÓKNISTYCH KOMPOZYTÓW POLIMEROWYCH STOSOWANYCH W STRUKTURACH LOTNICZYCH (Część 1)}

\section{Wprowadzenie}

Rozwój inżynierii materiałowej i nowe materiały konstrukcyjne mają istotny wpływ na rozwój technologiczny wielu dziedzin, a szczególnie lotnictwa [1,2]. Jako przykład przedstawiono graf dotyczący rozwoju doskonałości aerodynamicznej szybowców (Rys. 1)[3].

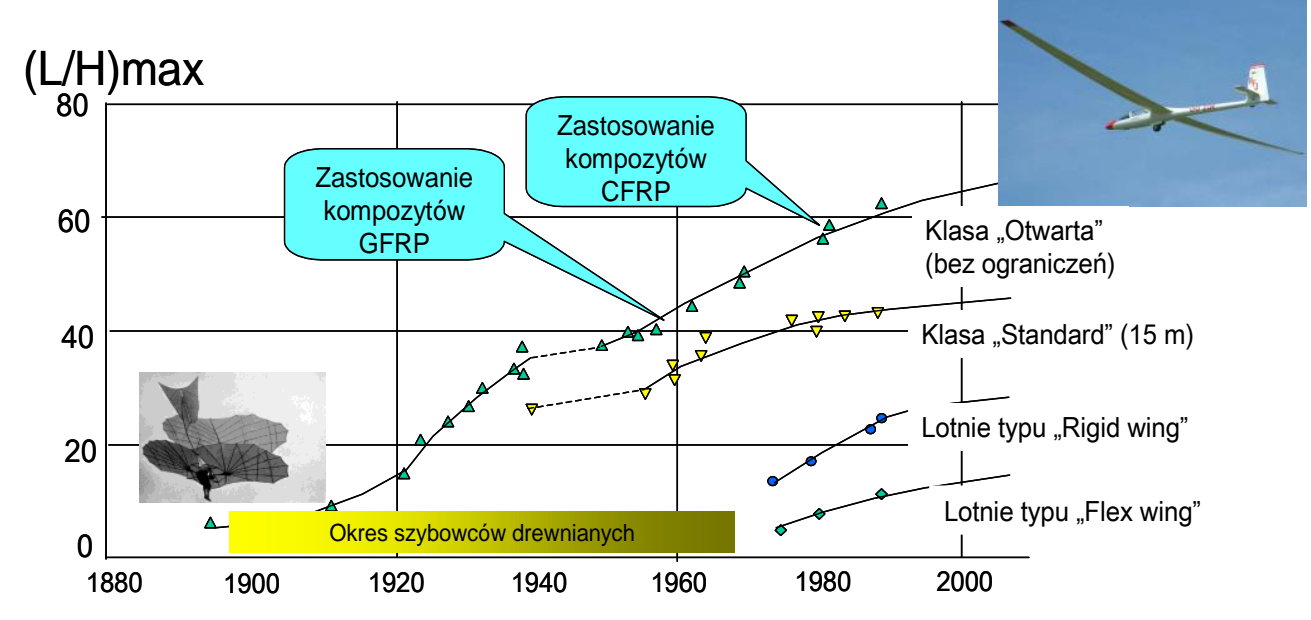

Rys. 1 Wplyw nowych materiałów na rozwój doskonałości aerodynamicznej szybowców [3]

Doskonałość aerodynamiczna jest definiowana jako stosunek siły nośnej $L$ do oporu aerodynamicznego $D$ lub jako stosunek współczynnika siły nośnej $c_{L}$ i współczynnika oporu aerodynamicznego $c_{D}$.

$$
\frac{L}{D}=\frac{c_{L}}{c_{D}}
$$

Wyrażenie na współczynnik oporu aerodynamicznego może być wyrażony jako suma następujących składników odnoszących się w kolejności do oporu aerodynamicznego profilu skrzydła, oporu indukowanego generowanego przez 3wymiarowy opływ skrzydła oraz oporu powodowanego przez szorstkość powierzchni skrzydła:

$$
c_{D}=c_{D_{-} \text {airfoil }}+c_{D_{-} \text {induced }}+c_{D_{-} \text {rough }}
$$


Składnikiem mającym najistotniejszy wpływ na wartość współczynnika oporu jest współczynnik oporu indukowanego. Jak wynika z zamieszczonego poniżej wzoru opór indukowany jest odwrotnie proporcjonalny do wydłużenia skrzydła $\lambda$. Tak więc (dla określonej wartości współczynnika siły nośnej) opór ten jest mały jedynie w przypadku, gdy rozpiętość $b$ jest odpowiednio duża w stosunku do średniej cięciwy aerodynamicznej.

$$
c_{D_{-} \text {induced }}=\frac{c_{L}^{2}}{\pi \cdot \lambda}=\frac{c_{L}^{2} \cdot S}{\pi \cdot b^{2}}
$$

Wymóg, aby skrzydło miało duże wydłużenie generuje szereg wymogów dotyczących materiałów o dużej wytrzymałości, jako, że skrzydło wysokowyczynowego szybowca pracuje jako wysoko obciążona cienka belka o małym przekroju poprzecznym. $Z$ tego powodu musi ona być skonstruowana z odpowiednim zapasem bezpieczeństwa przy jednoczesnej minimalizacji masy własnej. Tak więc rola materiału konstrukcyjnego ma tu szczególne znaczenie. Biorąc jako przykład krzywą dot. Klasy Otwartej (t.j. szybowcowej klasy zawodniczej -nie posiadającej ograniczeń konstrukcyjnych) - łatwo można zobaczyć, że zastosowanie włóknistych kompozytów polimerowych umożliwiło osiągnięcie znacznie większych doskonałości aerodynamicznych, niż w przypadku innych materiałów.

Na rys. 2 zostały przedstawione w schematyczny sposób linie reprezentujące wytrzymałość na rozciąganie dla różnych materiałów konstrukcyjnych stosowanych w aeronautyce dawniej i współcześnie. Zostały na nim przedstawione zakresy zachowań liniowych oraz wartości wydłużeń przy zerwaniu.

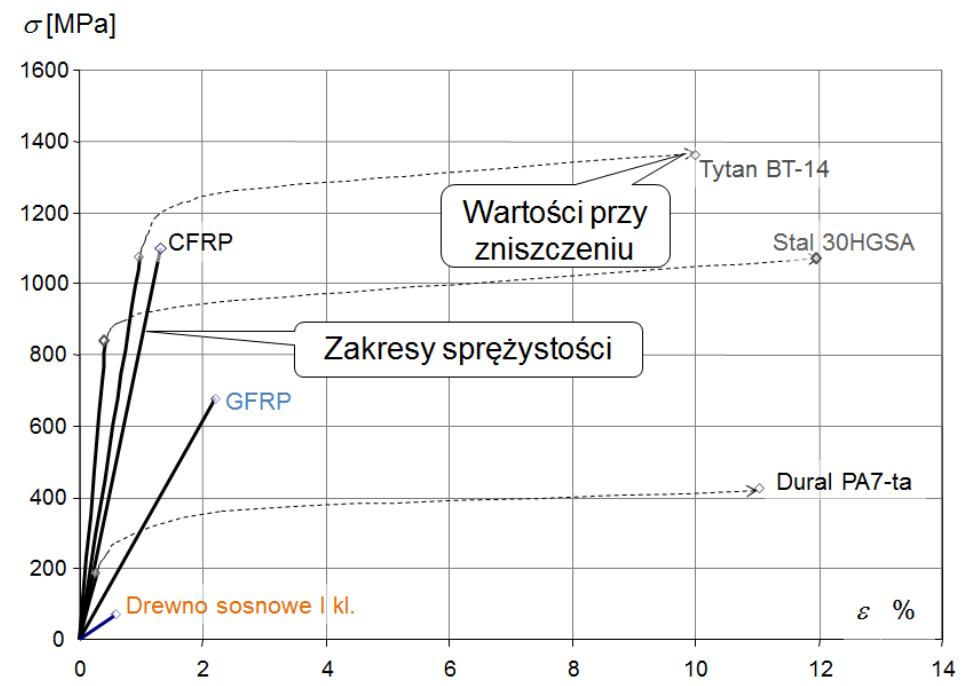

Rys. 2 Zakresy charakterystyk sprężystych oraz naprężenia $i$ wydtużenia przy zrywaniu dla materiatów użyanych do budowy struktur lotniczych 
Lightness factors and exertion factors related to its own mass of fiber... (Part I) Wskaźniki lekkości oraz wskaźniki wysiłku struktury w odniesieniu do...(Część I)

Z wykresu wynika, że największą wytrzymałość mają stopy tytanu i kompozyty na bazie włókien węglowych. Stal ma największy moduł Young’a, a właściwości drewna sosnowego (lotniczej jakości) prezentują się na tym tle bardzo skromnie. Trzeba jednak podkreślić, że ta analiza obejmuje jedynie wartości wytrzymałości wyrażone w $\mathrm{MPa}$, podczas, gdy masa materiałów jest niebrana pod uwagę.

Wartości liczbowe podstawowych właściwości wytrzymałościowych przedstawiono w lewej części Tab. 1.

Tab. 1 Wtaściwości wytrzymałościowe (w wartościac absolutnych lub względnych) dla materiatów używanych do budowy struktur lotniczych

\begin{tabular}{|l|c|c|c|c|c|c|c|c|}
\hline & $\begin{array}{c}\text { Wytrz. na } \\
\text { rozc. }\end{array}$ & $\begin{array}{c}\text { Wytrz. na } \\
\text { ścisk. }\end{array}$ & $\begin{array}{c}\text { Moduł } \\
\text { sztywn. }\end{array}$ & $\begin{array}{c}\text { Gęstość } \\
\text { wókna }\end{array}$ & Gęstość & Wytrz. & Wytrz. & Sztywn. \\
\hline & $R_{m}$ & $R_{c}$ & $E$ & $\rho$ & $\rho$ & $R_{m} /(\rho g)$ & $R_{c} /(\rho g)$ & $E /(\rho g)$ \\
\cline { 2 - 10 } & $\mathrm{MPa}$ & $\mathrm{MPa}$ & $\mathrm{GPa}$ & $\mathrm{g} / \mathrm{cm}^{3}$ & $\mathrm{~g} / \mathrm{cm}^{3}$ & $\mathrm{~km}$ & $\mathrm{~km}$ & $\mathrm{~km}$ \\
\hline GFRP & 680 & 600 & 35 & 2.55 & 1.875 & 37 & 33 & 1903 \\
\hline HT-CFRP & 1100 & 800 & 100 & 1.76 & 1.48 & 76 & 55 & 6888 \\
\hline HM-CFRP & 830 & 700 & 123 & 1.9 & 1.55 & 55 & 46 & 8089 \\
\hline AFRP & 790 & 180 & 44 & 1.45 & 1.325 & 61 & 14 & 3385 \\
\hline Tytan & 1400 & 1400 & 110 & - & 4.45 & 32 & 32 & 2520 \\
\hline Stal & 1100 & 1100 & 210 & - & 7.86 & 14 & 14 & 2724 \\
\hline Aluminum & 420 & 420 & 72 & - & 2.8 & 15 & 15 & 2621 \\
\hline Sosna I kl. & 69 & 39 & 12 & - & 0.46 & 15 & 9 & 2659 \\
\hline
\end{tabular}

Gdyby przyjąć, że jedynym kryterium konstrukcyjnym dla prętów rozciąganych jest minimalizacja przekroju, a masa jest nie istotna - to bez wątpienia stal, stopy tytanu i kompozyt węglowo-epoksydowy (CFRP) byłyby ekwiwalentnymi materiałami.

W aeronautyce jednakże występuje zazwyczaj potrzeba, aby wysokiej wytrzymałości towarzyszyła jak najmniejsza masa materiału lub struktury. W takim przypadku bardziej odpowiednim parametrem do porównań byłby wytrzymałość właściwa lub sztywność właściwa. Gdyby określić je wg wzorów zamieszczonych w Tab. 1 to wymiarem wytrzymałości właściwej byłby [m] lub [km], a liczby w kolumnie wytrzymałości właściwej oznaczałyby długość pręta, który urwie się (lub zgniecie) pod własnym ciężarem. Gdyby porównać ten właśnie parametr - to od razu staje się widoczna przewaga wszystkich rodzajów kompozytów włóknistych nad metalami. Co ciekawe - stal, stopy aluminium i drewno sosnowe mają niemal takie same wartości wytrzymałości właściwej i sztywności właściwej.

Rys. 3 przedstawia graf, na którym na osi pionowej zgrupowano wytrzymałości właściwe na rozciągania w na ściskanie, a na osi poziomej sztywności właściwe.

Stosunek odległości punktów reprezentujących różne materiały konstrukcyjny od początku układu współrzędnych zawiera informację ile razy różną sztywność lub wytrzymałość będą miały pręty o tej samej masie, lub ile razy różną masę będą miały dwa pręty o tej samej sztywności lub wytrzymałości. 


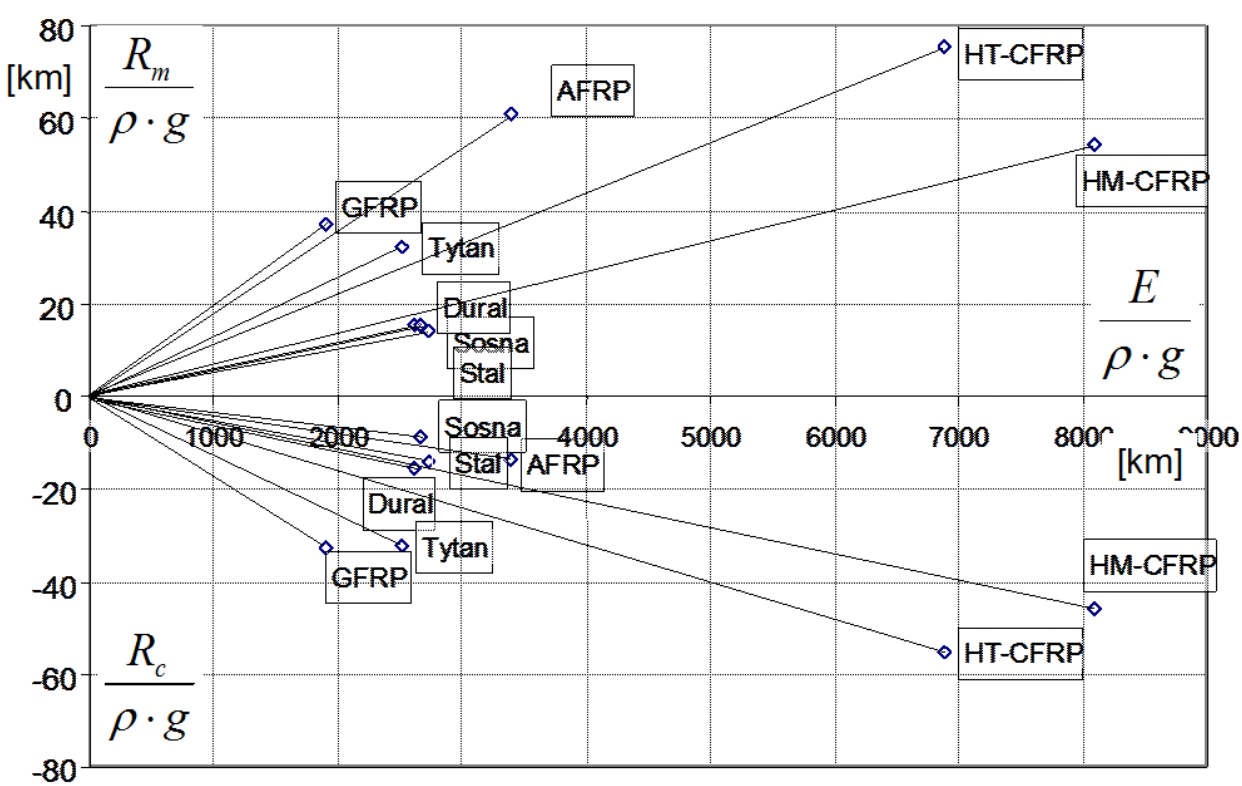

Rys. 3 Wytrzymałość właściwa i sztywność właściwa wybranych kompozytów (o strukturze UD) oraz metali i drewna

Graf ten ukazuje jak wielką przewagę mają kompozyty z włókien węglowych. Wynika z niego również, że masy struktur konstrukcyjnych $\mathrm{z}$ materiałów tradycyjnych o tej samej wytrzymałości będą podobne niezależnie od tego, czy są zrobione z drewna, stopów aluminium lub stali.

\section{Wskaźniki lekkości}

Wytrzymałość właściwa lub sztywność właściwa należą do zbioru tzw. wskaźników lekkości. Zbiór ten zawiera większą reprezentację tego rodzaju wskaźników [4]. Zostały one zgrupowane w Tab. 2.

Tab. 2 Wskaźniki lekkości struktury dla wybranych obciązeń [4]

\begin{tabular}{|c|c|c|c|c|c|}
\hline Element & \multicolumn{3}{|c|}{ pręt } & powłoka & rura \\
\hline \multirow[t]{2}{*}{ obciążenie } & \multirow[t]{2}{*}{ rozciąganie } & \multicolumn{2}{|c|}{ ściskanie } & \multirow{2}{*}{$\begin{array}{c}\text { utrata } \\
\text { stateczności } \\
\text { przy } \\
\text { ściskaniu }\end{array}$} & \multirow{2}{*}{$\begin{array}{c}\text { utrata } \\
\text { stateczności } \\
\text { przy } \\
\text { skręcaniu }\end{array}$} \\
\hline & & $\begin{array}{l}\text { sciskanie } \\
\text { prętów } \\
\text { krępych }\end{array}$ & $\begin{array}{c}\text { wyboczenie } \\
\text { Euler'ow skie } \\
\text { (ta sama smuklość) }\end{array}$ & & \\
\hline $\begin{array}{l}\text { wskaźnik } \\
\text { lekkości }\end{array}$ & $R_{m} / \rho$ & $R_{d} \rho$ & $E / \rho$ & $E^{1 / B / \rho}$ & $E^{1 / 2 / \rho}$ \\
\hline
\end{tabular}

Aby objaśnić genezę tych wskaźników, najlepszą drogą jest analiza stosunku mas dwóch elementów strukturalnych obciążanych w ten sam sposób aż do zniszczenia. 
Lightness factors and exertion factors related to its own mass of fiber... (Part I) Wskaźniki lekkości oraz wskaźniki wysiłku struktury w odniesieniu do...(Część I)

$$
\frac{m_{1}}{m_{2}}=? \quad \begin{aligned}
& \text { Porównanie mas ustrojów nośnych (prętów, } \\
& \text { powłok, itp.) zdolnych do przeniesienia tego } \\
& \text { samego obciażenia }
\end{aligned}
$$

Dla uproszczenia analizy założono, że materiały są quasi-izotropowe i ich właściwości sprężyste mogą być reprezentowane przez jedną wartość modułu Younga $E$, która odpowiada właściwościom kompozytu na kierunku działania obciążenia.

Przykładowo - dla prętów rozciąganych stosunek ich mas może być wyrażony poprzez równanie zamieszczone na Rys. 4 , w którym $R_{m}$ oznacza wytrzymałość na rozciąganie, a $p$ gęstość.

$$
\begin{gathered}
P \rightarrow P_{\max } \\
P_{\max }=R_{m} A \quad m=A l \rho=\frac{P_{\max } l \rho}{R_{m}} \\
\frac{m_{1}}{m_{2}}=\frac{P_{\max } l \rho_{1} R_{m 2}}{P_{\max } l \rho_{2} R_{m 1}}=\frac{\rho_{2}^{-1} R_{m 2}}{\rho_{1}^{-1} R_{m 1}} \\
\text { powiekroju poprz. }
\end{gathered}
$$

Rys. 4 Geneza wskaźników lekkości dla prętów poddanych rozciaganiu [4]

Dla prętów ściskanych, do których stosuje się model wyboczenia Euler'a stosunek mas jest wyrażony przez równanie przedstawione na Rys. 5, w którym występują ilorazy modułu E przez gęstość p.

$$
\begin{array}{r}
P \rightarrow P_{k r} \\
m=A l \rho=\frac{P_{k r} l^{2}}{c \Pi^{2} E i^{2}} l \rho=\frac{P_{k r} s^{2}}{c \Pi^{2} E} l \rho \\
l_{k r}^{2}
\end{array}
$$

Rys. 5 Geneza wskaźników lekkości dla prętów poddanych ściskaniu [4] 
W przypadku powłok ściskanych wzór na wskaźnik lekkości podany jest na Rys. 6 .

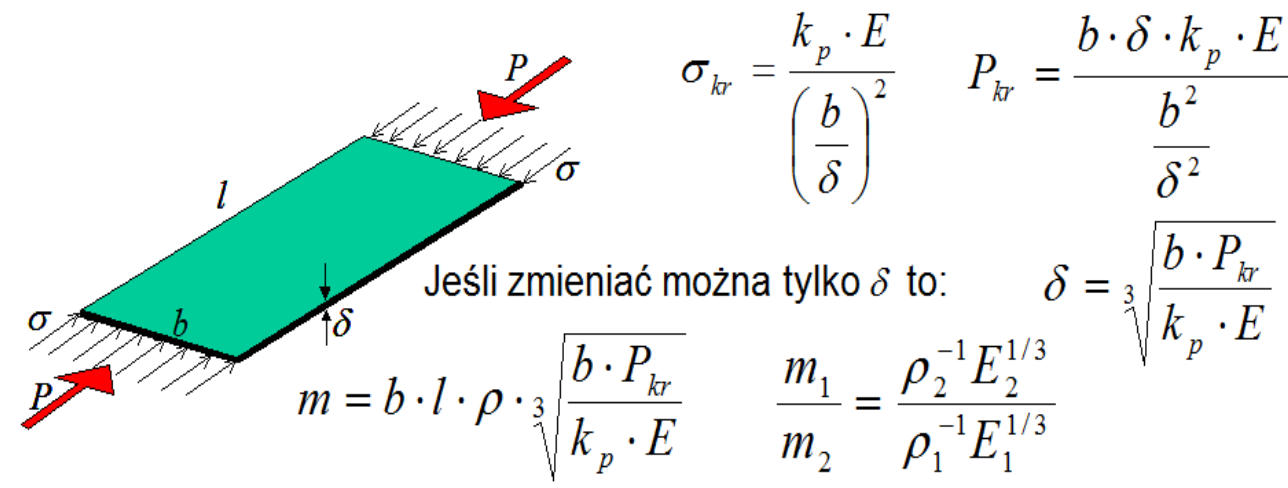

Rys. 6 Geneza wskaźników lekkości dla powłok poddanych ściskaniu [4]

$\mathrm{Na}$ koniec - przedstawiono przypadek powłok cylindrycznych poddanych skręcaniu (Rys. 7).

$$
\begin{aligned}
& \tau_{k r}=\frac{k_{c r} \cdot E}{\frac{D}{\delta}} \quad M_{t}=2 \cdot A \cdot \delta \cdot \frac{k_{c r} \cdot E}{\frac{D}{\delta}} \\
& \frac{m_{1}}{m_{2}}=\frac{\rho_{2}^{-1} E_{2}^{1 / 2}}{\rho_{1} E_{1}^{1 / 2}}
\end{aligned}
$$

Rys. 7 Geneza wskaźników lekkości dla powłok poddanych skręcaniu [4]

Modele obliczeniowe i rezultaty prezentowane powyżej są zgodne z literaturą źródłową [4], jednakże wzory na wskaźniki lekkości zostały wyprowadzone w odmienny sposób.

\section{Wskaźniki lekkości i wskaźniki wysiłku struktury powłok kompozytowych - obliczenia wysiłku struktury kompozytu $\mathrm{z}$ uwzględnieniem masy tkanin użytych w laminacie}

Poprzez analogię do wskaźników lekkości na początku lat 70-tych ubiegłego stulecia wprowadzono do obliczeń wytrzymałości struktur kompozytowych tzw. wskaźniki wysiłku struktury (Structure Stress Rates SSR). Wskaźniki takie pojawiają się także we współczesnej literaturze dot. projektowania struktur szybowców kompozytowych. 
Lightness factors and exertion factors related to its own mass of fiber... (Part I) Wskaźniki lekkości oraz wskaźniki wysiłku struktury w odniesieniu do...(Część I)

Wskaźnik wysiłku struktury powłoki kompozytowej wzmacnianej tkaninami rowingowymi jest zdefiniowany $w$ publikacji wydanej przez Niemieckie Stowarzyszenie Inżynierów VDI [ 5].

Definicja wskaźnika wysiłku struktury $\mathrm{K}_{\sigma}$ wyrażona jest równaniem (Rys. 8), gdzie $\sigma \cdot \delta$ oznacza wydatek siły rozciągającej lub ściskającej) względem wybranego kierunku ułożenia włókien:

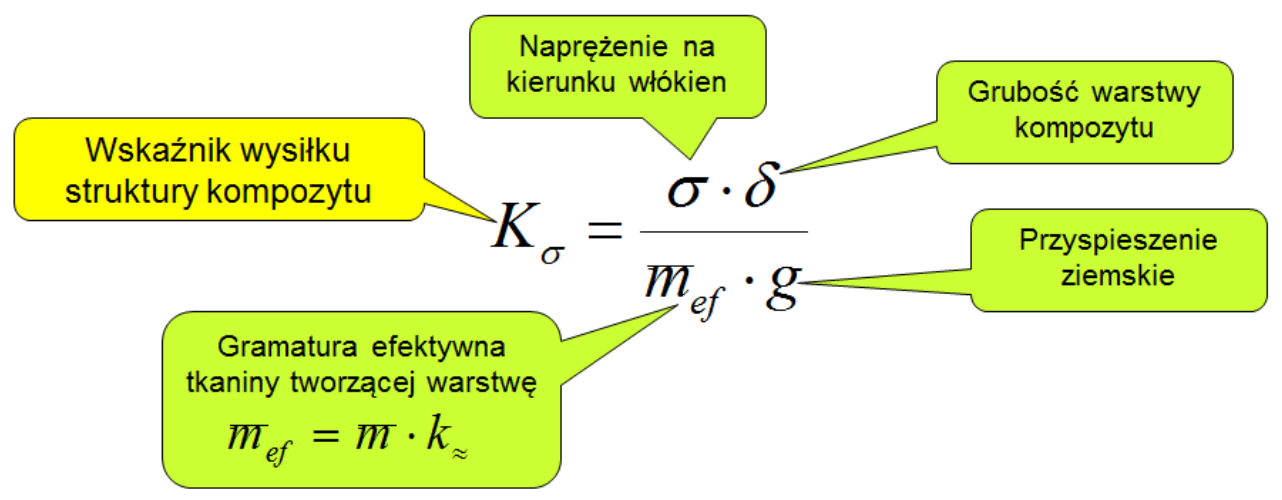

Rys. 8 Objaśnienie definicji wskaźnika wysitku struktury [5]

Symbol $\bar{m}$ oznacza sumę katalogowych wartości gramatury tkanin w laminacie, a $k_{\approx}$ oznacza udział masowy włókien ułożonych na kierunku przenoszonego obciążenia. Dla większości tkanin rowingowych posiadających tę samą ilość włókien w wątku i osnowie wartość $k_{\approx}=0.5$ o ile poddane zostały one obciążeniu (rozciągającemu lub ściskającemu) jedynie na jednym z kierunków zbrojenia (tj. wzdłuż wątku lub wzdłuż osnowy). Współczynnik $g$ oznacza przyspieszenie ziemskie. Jednostką $K_{\sigma}$ jest [m].

W literaturze źródłowej symbolowi $K_{\sigma}$ towarzyszy indeks $D$ lub $Z$ (który pochodzi od słowa "Drück” lub "Zuck” t.j. "rozciąganie” i „ściskanie”. Warto podkreślić, że największa możliwa wartość naprężenia $\sigma$ nie może przekroczyć wytrzymałości na rozciąganie lub ściskanie $R_{m}$ lub $R_{c}$. Wskaźnik wysiłku struktury dla tej wartości naprężenia jest wyrażony symbolem $K_{R m}$ lub $K_{R c}$ i jest specyficzną stałą materiałową. Wartość reprezentuje maksymalną długość włókien wątku lub osnowy (zależnie od kierunku przyłożonego obciążenia), które są w stanie przenieść obciążenie wywołane swoim własnym ciężarem. Gdyby porównać wartość $K_{\sigma} \mathrm{z} K_{R m}$ or $K_{R c}$ to można określić stopień wykorzystania zdolności przeniesienia obciążeń przez tkaniny zastosowane w powłoce kompozytowej.

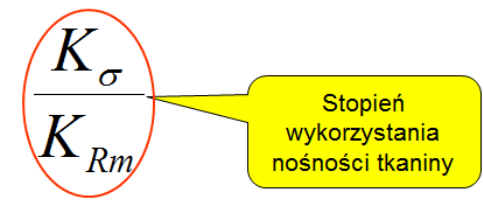




\section{Wskaźniki wytężenia struktury kompozytów włóknistych i metody obliczeń wytrzymałości laminatów}

Obecnie standardem w obliczeniach wytrzymałości laminatów jest wyrażenie wartości naprężeń oraz parametrów wytrzymałości w MPa (czyli obliczenia wg schematu ,siła dzielona przez przekrój poprzeczny materiału”). Jednakże dokładność takich obliczeń zależy bezpośrednio od dokładności określenia grubości warstwy kompozytu. Grubość warstwy kompozytu tworzonego z przesyconych polimerem tkanin zależna jest od metody wytwarzania (formowanie swobodne lub z dociskiem próżniowym). Przykładowo: jeśli ktoś użyje dwa razy więcej żywicy polimerowej do przesycenia pojedynczej warstwy kompozytu to grubość warstwy wzrośnie, ale rzeczywista wartość wytrzymałości będzie niemal ta sama. Zatem, jeśli do obliczeń wytrzymałości przyjmie on katalogową wartość $R_{m}$ oraz rzeczywistą grubość nadmiernie przesyconej warstwy laminatu - to popełni istotny błąd. Z tego powodu w przeszłości zastosowano metodę eliminacji grubości warstwy kompozytu ze wzorów obliczeniowych.

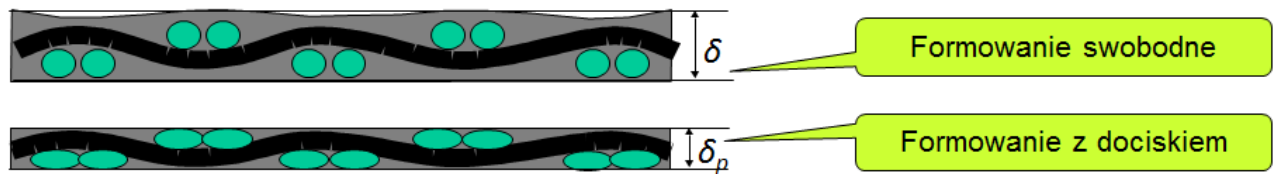

Rys. 9 Wpływ procesu technologicznego na grubość warstwy laminatu generujący problem, jaka wartość grubości powinna być brana do obliczeń wytrzymałościowych

Idea tej metody przedstawiona jest na Rys. 10. Zamiast naprężeń normalnych i tnących $\sigma$ lub $\tau$ użyte są wydatki siły normalnej i siły tnącej wzdłuż krawędzi kompozytu $q_{\sigma}$ lub $q_{\tau}$.

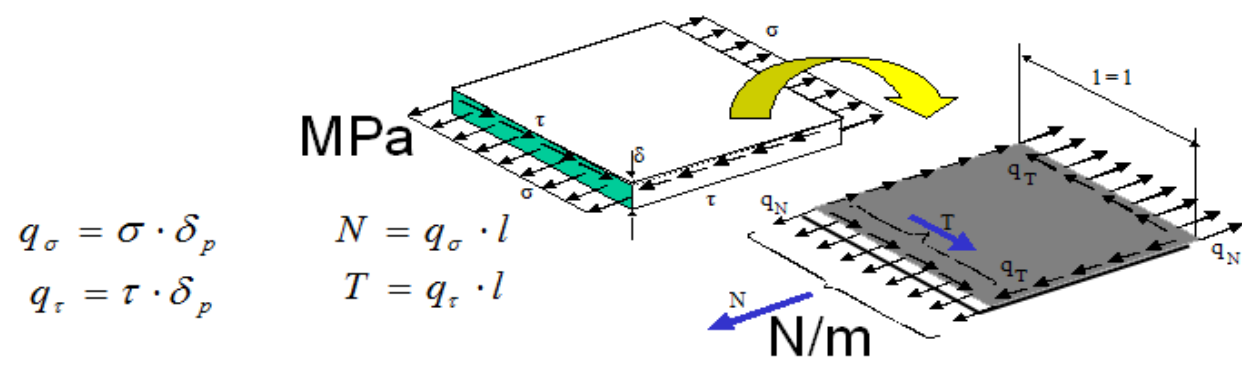

Rys. 10 Transformacja z systemu obliczeń "Sita \& pole powierzchni przekroju”" do system "Wydatek sity wzdłuż krawędzi laminatu \& dtugość krawędzi"

W konsekwencji zamiast stałych materiałowych $R_{m}, R_{c}, E, G$ (t.j. wytrzymałość na rozciąganie, wytrzymałość na ściskanie, moduł Young'a i moduł Kirchof’a) są użyte wielkości $\bar{R}_{m}, \bar{R}_{c}, \bar{E}, \bar{G}$, gdzie $R_{m}=R_{m} \cdot \delta$, itd.

Jednostką takiej stałej materiałowej jest $[\mathrm{N} / \mathrm{m}]$. 
Lightness factors and exertion factors related to its own mass of fiber... (Part I) Wskaźniki lekkości oraz wskaźniki wysiłku struktury w odniesieniu do...(Część I)

\section{Literatura}

[6] JBaker A. A.: Composite Materials for Aircraft Structures, Second Edition (AIAA Education Series), 2004.

[7] Kustron K.: The design technology development of prospective airframe in view of the operation\&maintenance experience and technology development, Journal of KONBiN 2 (22) 2012.

[8] Kensche Ch. W.: The influence of materials on the development of sailplane design, Technical Soaring, Volume XXVTT - July 2003

[9] Jancelewicz B.: Podstawy konstrukcji lotniczych z kompozytów polimerowych, Wyd. ITWL Warszawa 2000.

[10] Verein Deutscher Ingenieure: „Dimensionieren von Bauteilen as GFK” (Glasfaserstärkte Kunststoffe) - VDI 2013 Blatt 1, Düsseldorf 1973.

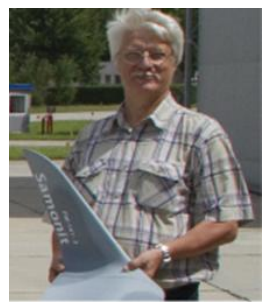

Dr hab.inz. Mirostaw Rodzewicz zatrudniony jest na stanowisku profesora $w$ Instytucie Techniki Lotniczej $i$ Mechaniki Stosowanej Wydziatu Mechanicznego Energetyki i Lotnictwa w Politechnice Warszawskiej. Ukończyt Wydz. MEiL w 1978r. Również na tym wydziale obronit rozprawe doktorka (1993 r.) i rozprawe habilitacyjna (2009 r.). Glównym obszarem zainteresowań jest mechanika eksperymentalna, technologia konstrukcji kompozytowych, badania statyczne $i$ badania zmęczeniowe kompozytowych struktur lotniczych, badania $w$ locie $i$ wyznaczanie spektrów obciązeń, a także projektowanie, budowa i testy samolotów bezzałogowych, a także ich aplikacja (Udziat 50\%).

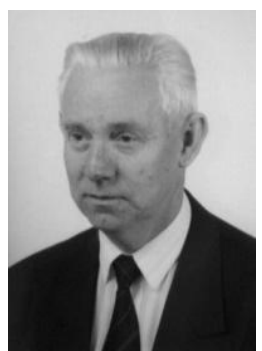

Prof. dr hab. inz. Jerzy Lewitowicz. .Absolwent WAT (1956r.): lotnictwo i UW (1961r.) fizyka jądrowa. Główne zainteresowania naukowe: technika wojskowa, kosmiczna, budowa i eksploatacja samolotów i śmigłowców.. Posiada ponad 60. letni staż naukowy $i$ dydaktyczny w Instytucie Technicznym Wojsk Lotniczych i na Politechnice Warszawskiej. Wieloletni czlonek SIMP, AIAA, ICAS, trzech komitetów Polskiej Akademii Nauk: Fizyki, Budowy Maszyn, Badań Kosmicznych i Satelitarnych. W autor ponad 400 publikacji naukowych; autor lub współautor 25 ksiażek, 27 wynalazków, ponad 450 opinii $i$ recenzji naukowych, uczestnik ponad 120 konferencji naukowych. Laureat wielu nagród naukowych $w$ tym Mistrza Techniki Polskiej, rektora PW, „Błękitne Skrzydta”, MON, MEN., Min. Transp. laureat nagrody TECHNICUS 2012 (Udziat 50\%). 